\title{
Research on the Construction of Ecosystem in Compliance Risk Management of Foreign Trade Enterprises in Fujian Province*
}

\author{
Yan $\mathrm{Hu}$ \\ Xiamen Huaxia University \\ Xiamen, China
}

\begin{abstract}
The contradiction between the frequent occurrence of global compliance risk and the imperfect compliance-risk management of China's foreign trade enterprises will become the bottleneck that affects China's foreign trade enterprises and the development of China's foreign trades. With the development of China's foreign trade and the need of regional economy and legal development, it is of great significance to strengthen the compliance management of foreign trade enterprises. This article takes the current situation of compliance management of foreign trade enterprises in Xiamen as an example, and proposes relevant measures to build an ecological system of compliance-risk management of foreign trade enterprises in Fujian Province.
\end{abstract}

Keywords-Fujian Province; foreign trade enterprises; compliance management

\section{INTRODUCTION}

Compliance usually consists the following three contents: firstly, to comply with the laws, which means the enterprises should abide by the laws and regulations of the place where its business activities are in order to ensure that its economic activities are in line with the public interests; secondly, to abide by the rules which means that the enterprises should follow the relevant rules and regulations formulated internally; finally, to obey the norms which means that the enterprises, in the process of complying with the rules and regulations, requires the employees of the enterprise to comply with the corresponding professional and moral ethics.

Strenthening the compliance construction can increase the security level of the trades and decrease the risk of supplying chain, meanwhile trade facilitation can improve the efficiency of customs clearance, which has been moving forward the development of foreign trade. The importance of compliance management is reflected in the following parts :

First of all, compliance management helps to prevent the compliance risk. Compliance risks are referred to the risk that an enterprise may suffer from legal sanctions, regulatory penalties, major financial or reputation loss due to its failure to comply with laws, regulatory provisions, rules and

*Fund: "Research on the Construction of Ecosystem in Compliance Risk Management of Foreign Trade Enterprises in Fujian Province"(Project No.: JAS180815), Education and scientific research project of young and middle-aged teachers in Fujian Education Department in 2018 relevant standards formulated by self regulatory organizations. Compliance risk is one of the core risks faced by all enterprises. If the enterprise involves serious violations, it may bring bankruptcy or such serious consequences.

Secondly, compliance management helps to reform managerial system. Compliance management is a process of optimization and improvement by integrating the concept of compliance management with the original business process and management system, so as to build a compliance system that meets the requirements of compliance management in line with the business development goals, in order to make enterprise management in spiral upward. Through reorganization and integration compliance management complete the reconstruction of enterprise management system.

Lastly, compliance management is conductive to increase the level of compliance culture. Each employee is highly involved in compliance management, thus having qualified employees with compliance culture can prevent compliance risk effectively. Therefore during the process of compliance management system construction, enterprises should be dedicate to the promotion of corporate compliance culture and philosophy through internal compliance training and cultural propaganda such methodologies.

With the further development of economic globalization and the vision of "The Belt and Road Initiative" , the international trading conditions faced by foreign trade enterprises have been through fundamental changes. Enterprises are faced with a large number of compliance risks. Therefore, only by strengthening the compliance management system can protect enterprises from compliance risks in order to remain invincible.

\section{THEORETICAL ANALYSIS OF COMPLIANCE MANAGEMENT}

Foreign trade enterprises make an evaluation of trade behavior by taking the cost analysis of compliance and violation as well as its own risk, so as to make a rational choice of compliance and violation. Enterprise compliance management is mainly influenced by internal and external factors. 
legal supervision environment mainly refers to legislation, application and enforcement of law, etc.

Legislation establishes the objective costs and profits of compliance and violations, and the quality of law enforcement will determine the actual expected costs of violations. Legal supervision environment is an important aspect affecting the cost-profit analysis of enterprises. Badach and Kagan pointed out even when the costs exceeded the profits, enterprises still might choose non-compliance in case of inappropriate law enforcement.

The second is the the economic environment. The second external variable that affects compliance behavior is the economic environment. Firstly, the economic environment affects the cost of compliance. In the study, Sonnenfeld pointed out that a good business environment would promote enterprises to achieve compliance management; secondly, the economic environment also affects the cost-profits of enterprises. Huisman pointed out due to the change of situation, the normal support for compliance might be weakened; finally, the economic environment can also promote a sustainable development of compliance. In their research, Konar and Cohen noticed the companies with the worst fall in share prices would try their best to reduce their pollution emissions.

The third is the the social environment. The impact of social environment on compliance has two sides. Through researches, it is found that social environment could effectively affect the compliance behavior of enterprises. For example, Indonesia's "Pollution control, assessment and rating program" and the US's "List of hazardous substance emission" effectively regulate corporate compliance behaviour; when the legal provisions are not supported or the legislature does not have sufficient legitimacy such special circumstances, the social environment may also become a direct induction factor for corporate violations.

It can be seen that the compliance work involves many aspects such as government and enterprises, especially in developing countries such as China. It is a must to fully understand various factors and the interaction of these factors in order to effectively study the compliance behavior and adjust the development strategies of enterprises based on the study results.

\section{INVESTIGATION AND ANALYSIS ON COMPLIANCE MANAGEMENT OF FOREIGN TRADE ENTERPRISES IN FUJIAN PROVINCE}

Fujian province is the second round of China's FTA pilot area, and it is also one of the strategic-point provinces of "The Belt and Road Initiative". The advantageous location, policy support, economic transformation, industrial upgrading and other more factors have made Fujian's economic development more effective and its economy and trade more active. However, in the process of high-speed development, problems still exist such as low efficiency of customs clearance, imperfect internal construction of private enterprises as an important pillar force in foreign trade development, and enterprise violations. Therefore, it is 
possibilities to improve their customs credit rating in order to have more customs clearance facilitations. construction of foreign trade enterprises in Fujian Province and promote the sustainable and healthy development of foreign trade.

In order to better understand the compliance management of foreign trade enterprises in Fujian Province, this paper designs a questionnaire which is mainly addressed to relevant foreign trade enterprises in Xiamen Free Trade Zone, with a total of 500 copies and 475 copies were completed with effective information, of which $19 \%$ of state-owned enterprises, $67 \%$ of private enterprises and $14 \%$ of foreign enterprises. Xiamen is a typical frontier city in Fujian Province, with the first ranking place in total amount of foreign trade import and export, so it has certain representativeness in compliance management of foreign trade enterprises. The enterprises investigated by the survey are mainly production-oriented enterprises with their own production bases and self-independent in import and export business, supplemented by logistics and agent-based trade enterprises. Here are the results of this survey :

\section{A. Foreign Enterprises and State-owned Enterprises Pay More Attention to Corporate Compliance Management}

In the enterprises who participated in the survey, the proportion of state-owned enterprises and foreign enterprises with professional functional departments responsible for compliance risk management has reached 100\%, while private enterprises have slightly insufficient attention to compliance management, accounting for $78 \%$; the proportion of state-owned enterprises with professional compliance officers has reached $100 \%$, foreign-funded enterprises account for $57 \%$, while private enterprises only account for $19 \%$; In whether relevant compliance policies are made in foreign trade enterprises, state-owned enterprises and foreign-funded enterprises account for more than $85 \%$, while private enterprises only account for $50 \%$. Nearly half of private enterprises do not have relevant compliance policies.

\section{B. Foreign Trade Enterprise Staff's Participation in Compliance Management Training Still Needs to Be Strengthened}

"Enterprises' staff only learn part of the knowledge about compliance management" is the most mainstream training situation in this survey, accounting for $40 \%, 38 \%$ of "staff seldom learn", and only $17 \%$ of "very detailed learning". It is noteworthy that still nearly $5 \%$ of the companies investigated by the survey have never conducted any relevant training.

\section{Customs Credit Rating of Foreign Trade Enterprises to be Improved}

In this survey, it is found that $50 \%$ of the customs credit rating of foreign trade enterprises is average, and only $15 \%$ of the customs credit rating of foreign trade enterprises is high. It should be noted that $4 \%$ of the foreign trade enterprises have been downgraded by the customs as dishonest enterprises due to their past violations. This phenomenon shows that many enterprises still have

\section{Royalties Have Become the Main Compliance Risk for Foreign Trade Enterprises}

Among the main compliance risks faced by enterprises (multiple choice), nearly $38 \%$ of them choose "Royalties", which has a direct relation with the current global countries' efforts to increase the protection of intellectual property rights, trademark rights and other concessions; trade mode ranks second position, accounting for $27 \%$, equipment accounts for $23 \%$, express samples accounts for $17 \%$, and More or Less Clause accounts for $10 \%$.

\section{E. Social, Political and Economic Environment Is the Main Reason for Generating Compliance Risk of Foreign Trade Enterprises} (multiple choice), "social political and economic environment" is recognized the momst by the questionnaired enterprises, accounting for $40 \%$, which coincides with most of the research results; "uncertainty of regulatory policy" ranks the second, accounting for 35\%, and "high compliance cost" making the enterprises rather taking risks, accounting for $30 \%$, of which the compliance cost of private enterprises is higher than that of state-owned enterprises and foreign enterprises, and the compliance cost of small enterprises is higher than that of medium and large enterprises; "there is no corresponding policies within the company" accounts for $15 \%$, and "there is no comprehensive understanding of external regulatory policies" accounts for $8 \%$.

\section{CONSTRUCTION OF COMPLIANCE MANAGEMENT ECOSYSTEM FOR FOREIGN TRADE ENTERPRISES}

According to the analysis of the survey results of compliance management of foreign trade enterprises, it is believed that the construction of compliance management ecosystem of foreign trade enterprises requires the joint efforts of the government, enterprises and other parties.

\section{A. The Government Strengthens the Promotion of Compliance Supervision}

In recent years, more and more attention has been paid to the problem of Chinese enterprises' violation, which has a direct impact on the image of the country and the sustainable development of enterprises around the world. Against the background of economic globalization, "The Belt and Road Initiative" and the construction of a free trade zone, government should set more policy guidance and industry norms in the construction of compliance system, accelerate the absorption of advanced experience abroad, form national standards, improve relevant laws and regulations, intensify supervision and enforcement, and promote the internationalization of corporate compliance governance.
In the survey on the causes of enterprise compliance risk 
managers, resulting in the phenomenon of "one person

B. Enterprises Strengthen the Construction of Their Own Compliance Ecosystem

In order to establish an effective compliance ecosystem, foreign trade enterprises need to be good at identifying the compliance risks faced by the enterprises, establish and improve the compliance management system based on the compliance risks, meanwhile strengthen the compliance training internally, and set up specific compliance position to supervise the compliance behaviors of enterprises. A relatively feasible compliance management ecosystem is explored from the following aspects for enterprises.

1) Compliance risk learning in compliance management: First of all, comprehensive learning of compliance knowledge should be carried out. The results of the questionnaire show that many enterprises, especially private companies know very little about compliance risk, and many foreign trade enterprises rarely conduct any comprehensive and systematic training and learning of compliance knowledge for their employees, which result in many cases of violations. Foreign trade enterprises should strengthen the internal compliance training, and actively invite the regulatory department to the enterprise to do the legal popularization training so as to improve the overall compliance awareness of the enterprise. Compliance learning can help enterprises identify risks effectively, which is the prerequisite for constructing enterprise's compliance management system.

2) Construction of compliance system: The content and scope of the enterprise's compliance management system are closely related to the enterprise's business activities. When designing and formulating the compliance management system, it is necessary to look at 3 different layers, macro, meso and micro, and draw up a set of compliance management policies which can not only guarantee the enterprise to fulfill the compliance obligations and meet the relevant compliance requirements, but also help the enterprise achieve its own development goals. On the macro layer, we need to fully understand the social, political, economic, legal and other development level and requirements of the country or trading partner's country; on the meso layer, understand the market environment and customer demand of the industry, especially focus on analyzing the policies and norms of relevant industries; on the micro layer, based on the enterprise objectives, scale, cost-effectiveness, etc., establish a compliance management system suitable for the sustainable development of enterprises.

3) Compliance supervision management: First of all, the compliance power should be poured into the decisionmaking level of the enterprise, from the top to the bottom, to promote the most effective implementation of compliance within the enterprise; secondly, there should be a special compliance supervision and management department internally. In the process of the survey, we found that many compliance managers of private enterprises are the decides"; finally, the enterprise should strengthen the scientific management manner, such as big data management and sharing various data within the enterprise, in order to effectively prevent the occurrence of employees' violations.

\section{Compliance Outsourcing Services Provided by the Third Party}

In recent years, with the improvement of the law, the government's supervision over the enterprises has been strengthened day by day, and various administrative departments have increasingly spot checked on the compliance of enterprises. As small and medium-sized enterprises, on one hand, they need to accept the supervision of industry and commerce, quality supervision and other administrative departments, on the other hand, the enterprise's legal department lack of the professional knowledge, so they can't respond to the government investigation in the most effective way. The third-party with outsourced service can provide small and medium-sized enterprises with the prevention mechanism, help enterprises maintain the relationship with the government, provide legal advice, formulate responsive strategies, conduct legal defense for enterprises, safeguard the legitimate rights and interests of enterprises and other professional compliance services, so that the enterprises can focus on business affairs and reduce the burden during business operation.

\section{CONCLUSION}

It can be seen that governments, enterprises and professional legal institutions should coordinate their development with response to international rules and standards, in order to face more fierce international competition and seek new opportunities for global development in today's globalization. Therefore, it is of great significance to strengthen the compliance management of an enterprise and build the compliance culture to promote foreign trade enterprises in Fujian Province to go abroad, upgrade to a high-end industry chain and a sustainable development.

\section{REFERENCES}

[1] Zhile Wang. Enterprise compliance management operation guide[M] Beijing: China Legal Publishing House, 2017:012

[2] Jin Chen. B Research on trade compliance risk of processing trade enterprises[D]. Nanjing: Nanjing University, 2016.8-15. (in Chinese)

[3] Quanming Zhang. Challenges on compliance risk with the construction of compliance system by state owned enterprises [J]. China Accounting Journal, 2017(8):01-02. (in Chinese)

[4] Shuguang Zhang. Actively respond to the compliance risk of "The Belt and Road Initiative" and take the lead in building and improving the compliance management system [J]. International Engineering and labor service Magazine, 2018(2):26-27. (in Chinese)

[5] Tao Yang. ISO19600 Interpretation of international standards of compliance management system guidelines $[\mathrm{J}]$. Popular Standardization, 2017:43-45. (in Chinese)

[6] Litong Chen. Commercial Bribery Risk Management [M]. Beijing: China Economic Publishing House, 2014:012. (in Chinese) 